\title{
The Gender Effect on Banking Performance in Indonesia
}

\author{
Suwinto Johan* \\ Sekolah Tinggi Manajemen PPM \\ Jakarta, Indonesia \\ *suwinto.johan@gmail.com
}

\author{
Claudia Gita Hapsari \\ Universitas Tarumanagara \\ Jakarta, Indonesia
}

\begin{abstract}
This paper aims to study the determinants of banking performance from human equality perspective. Banking is a service industry which heavily depends on the human resources. Therefore, the research will focus on the diversity of employees and board member in determining the financial performance. We have analysed 2 ratios which are the gender diversity of total employees and gender diversity in board members. The dependent variable is Return on Asset (ROA). We use linear regression. The samples are 11 banks which are categorized under book 4 and book 3 as per Indonesia Central Bank. The empirical result shows that the board member diversity significantly influences the banking performance. However, the diversity has negative influence on the banking performance.
\end{abstract}

Keywords—banking, diversity, firm performance, gender

\section{INTRODUCTION}

Gender equality is one of the most important aspects of a society. Gender equality is a fundamental human right as mentioned in the United Nations' Universal Declaration of Human Rights. This is shown by the importance of female candidates' participation in the 2019 Indonesian People's Representative Council based on the Law of The Republic of Indonesia Number 7 of 2017 on Election [1]. In addition, gender equality has become one of the key factors in employee recruitment. Companies are prohibited from discriminating a profession due to gender differences.

Based on the national census conducted by Indonesian Statistic Bureau (Biro Pusat Statistik or BPS), the number of female population in Indonesia is 131.58 million and the number of male population in Indonesia is 130.31 million. The total population of Indonesia according to the 2017 national census was 261.99 million. The number of population has increased by $10 \%$ from 236.64 million since 2010 . The number of female population has also increased by $11.50 \%$ from 118.01 million. There are 101 males for every 100 females. The male population outnumbers the female population.

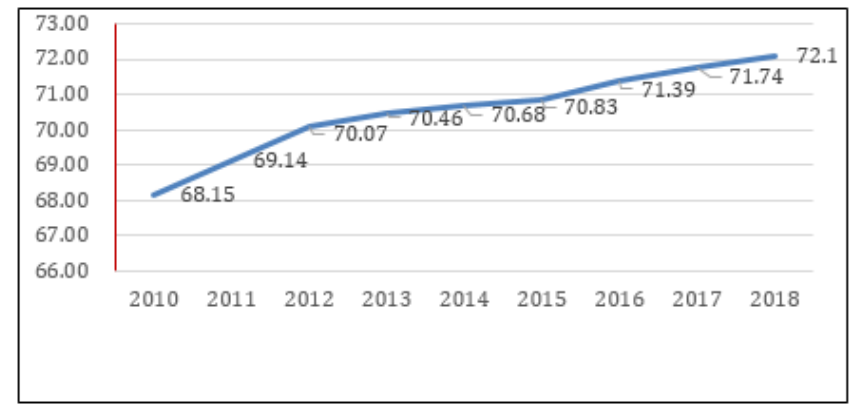

Fig. 1. Women empowerment index [2].

Based on Indonesian Statistic Bureau, majority of Indonesian population is in the range of the working age. The total percentage of female in the working-age category is $67.38 \%$. The numbers of female and male in the working-age category are equal.

Women Empowerment Index, an index of women's involvement in social, economics, and politics environments, shows an uptrend from 2010 to 2018 as shown in Figure 1. In addition, the women's involvement in the professional workforce has also increased from $44 \%$ in 2010 to $47 \%$ in 2018 as shown in Figure 2 [2].

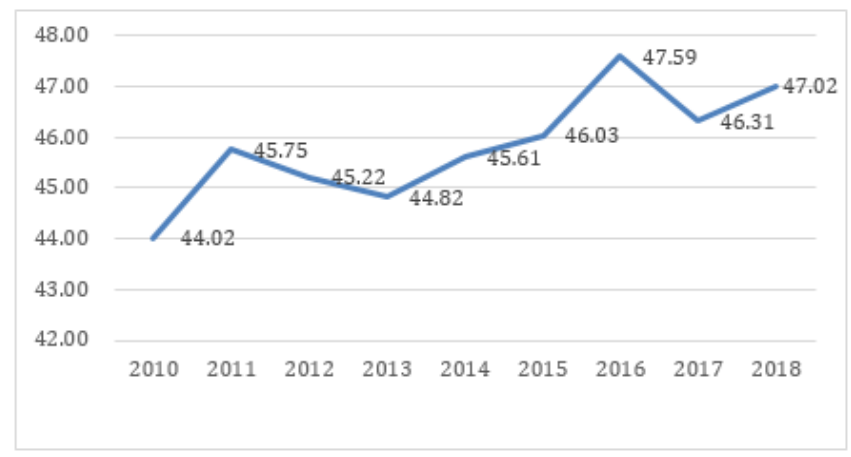

Fig. 2. Women in professional workforce [2]. 


\section{LITERATURE REVIEW}

The board of directors diversity and its relationship with the performance of the institution. This research finds that board of directors' diversity has a significant relationship with the financial performance of the institution [3]. Moreno-Gómez et al. [4] discovered that gender diversity contributes positively to the business performance, especially on its Return on Assets (ROA). Female representation as members of the board also contributes positively to Return on Equity (ROE).

The listed companies are benefited from the increasing gender diversity in their board of directors, which helps the company to balance the economic development and social cohesion to achieve sustainable development [5].

Furthermore, Handa [6] established that bank performance is significantly influenced by average remuneration, the duality of Chairman-CEO roles, female directors, and board committees. Ramly et al. [7] reviewed the role of female board members in increasing banking efficiency conducted on 102 banks in ASEAN-5 from 1999 to 2012. The research showed that female board members give significant and positive contribution on banking efficiency. This result contrasts with the literature review. The literature review shows finds that female board members do not give a significant contribution on efficiency. This research result also found that female board members are more effective as independent directors.

Some previous studies, Volonté and Gantenbein [8] analysed 560 companies in Switzerland to discover how the company performance is influence by the background of human capital managers. This study found that as long as that the human capital managers' background is related to the company strategy, it will influence the performance of the company. Nguyen et al. [9] utilized the generalized method of moments (GMM) to study 315 companies in Vietnam and concluded that human capital directors create added values to the company. This research supports the qualification standardization for directors in Vietnam.

Finally, Mohammad et al. [10] concluded that based on statistic measures, the percentage of women as members of board and middle to top managers does not have a significant relation with the financial performance of banks. And, Saleh [11] found that the size of the board does not influence the financial performance. However, the diversity and composition of the board influence the financial performance significantly. In addition, Hassan [12] also discovered that managers, stakeholders, shareholders, and potential investors acknowledge the importance of diversity in measuring the value of the firm.

In addition, Širec and Mocnik [13] found that firm's profitability is determined significantly by the size of the firm, specifically for the male-owned firms only. Based on the profitability and cost of labor, it is indicated that the cost of labor influences the profitability male-owned firms with highgrowth positively. Next, Jadah et al. [14] recommended that banks should improve their financial performance better by selecting non-executive directors in their board of directors with few female members in the board. And, Shukla et al. [15] found that the duality of CEO, meeting frequency, and average number of board members have a positive influence on the market performance of banks in India. The research does not explore the characteristics of stakeholder relations committee, risk and remuneration committee, and audit committee.

The implication of board of directors and CEOs' diversity on banking performance conducted on 54 public banks in England from 2005 to 2015. This research discovered that the diversity of board of directors has a significant signification association with the banking performance [16]. And then Endraswati [17] showed that the Indonesian sharia banking is negatively influenced by the proportion of women directors. Sharia banking performance is also influenced by other variables, such as education background of the female directors, firm size, and women's tenure. Moreover, Khan [18] concluded employees are influenced directly by the training and education. Education expands knowledge, improves skills, shapes attitudes, and empowers motivation, while training converts them into human capital which is beneficial to improve the productivity of the firm.

Next, Khan et al. [19] found that Islamic banks with fewer female directors show higher risk and inefficiency, compared with the conventional banks. Profitability and interest margin are also unrelated to the risk and inefficiency in this research. Arnaboldi et al. [20] indicated that the bank performance is influenced positively by the board diversity. The continuing the voluntary expansion of gender diversity on bank board will be value-enhancing, provided that they are well capitalized [21]. Dries [22] showed that a high level of gender diversity in management boards of European banks has negative effect on performance. The presence of women is not necessarily negative, but that the effect becomes negative if this leads to an increase in gender diversity.

There is a tendency for the females to work in firms with high profitability. In return, they also contribute to the high increase in the firm's profitability [23]. Abu et al. [24] recommended that the banks in Nigeria should add more foreign members to their board of directors to utilize their experience, expertise, skills, and competence. In addition, they also suggested that there are too many grey directors in the board, so it has to be reduced to only an average of three or four directors.

The diversity of gender in the membership of board of directors and its influence on the performance of banks [25]. This research was conducted on 10 banks in Pakistan from 2005 to 2016. Financial performance variable in this study was measured based on ROE and ROA. Fatima and Sharif [26] studied 119 financial institutions in Asia and concluded that the financial institutions' performance is not influenced by gender diversity. This research found that Return on Average Assets (ROAA) is significantly influenced by age diversity and background. 
TABLE I. PRIOR RESEARCHES

\begin{tabular}{|l|l|l|}
\hline \multicolumn{1}{|c|}{ Variable } & \multicolumn{1}{|c|}{ Researchers } & \multicolumn{1}{|c|}{$\begin{array}{c}\text { Effect on The } \\
\text { Performance of } \\
\text { Financial Institution }\end{array}$} \\
\hline $\begin{array}{l}\text { Female Representation } \\
\text { on Board of Directors' } \\
\text { Diversity }\end{array}$ & $\begin{array}{l}{[3],[8],[9],[4],} \\
\text { Significant }\end{array}$ & \\
\hline $\begin{array}{l}\text { Number of Female } \\
\text { Employees Compared to } \\
\text { Total Employees }\end{array}$ & {$[16],[25],[26]$} & Not Significant \\
\hline
\end{tabular}

This research studies the effect of good governance, specifically the composition of female employees and women diversity in the board members, on Book 4 and Book 3 banking performance in Indonesia from 2015 to 2018. The number of sample is 11 banks. The variable of banking performance is Return on Assets (ROA). This variable has been studied by Moreno-Gómez et al. [4] and Chandani et al. [25].

The independent variables are the composition of female employees and women diversity in the board members. The research objectives are 1) does employees gender influence the Return on Asset of banks in Indonesia? 2) does board of directors gender influence the Return on Asset of banks in Indonesia?

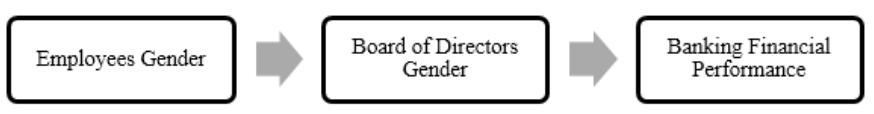

Fig. 3. Conceptual framework.

\section{METHOD}

The model of this research is:

$$
Y_{i t}=a+b_{1} K a r W_{i t}+b_{2} \operatorname{Dir}_{i t}+\varepsilon
$$

Description:

$$
\begin{array}{ll}
\mathrm{Y}_{\mathrm{it}} & =\text { return on asset } \text { and firm size } \\
\text { KarW } & =\text { number of female employees } \\
\text { DirW } & =\text { gender composition of female board } \\
& \text { members }
\end{array}
$$

The hypothesis of this research are as follows:

TABLE II. HYPOTHESIS

\begin{tabular}{|l|l|l|lr|}
\hline Hypothesis & Determinant & \multicolumn{1}{|c|}{ Variable } & \multicolumn{2}{|c|}{$\begin{array}{c}\text { Relationship - } \\
\text { Effect }\end{array}$} \\
\hline H1 & $\begin{array}{l}\text { Corporate } \\
\text { Governance }\end{array}$ & $\begin{array}{l}\text { Number of } \\
\text { Female } \\
\text { Employees }\end{array}$ & $\begin{array}{l}\text { Significant on } \\
\text { ROA }\end{array}$ & \\
\hline H2 & $\begin{array}{l}\text { Corporate } \\
\text { Governance }\end{array}$ & $\begin{array}{l}\text { Number of } \\
\text { Female Board } \\
\text { Members }\end{array}$ & $\begin{array}{l}\text { Significant } \\
\text { ROA }\end{array}$ \\
\hline
\end{tabular}

Source: data processe
This research analyses the secondary data published in the annual reports of banking institutions from 2015 to 2018. The classifications of Book 4 and Book 3 banks are based on the category regulation of Bank Indonesia/Financial Services Authority (OJK). [27] The definitions of the research variables are shown in the following table:

TABLE III. RESEARCH VARIABLES

\begin{tabular}{|l|l|}
\hline \multicolumn{1}{|c|}{ Variable } & \multicolumn{1}{c|}{ Definition } \\
\hline Employees Gender Composition & $\begin{array}{l}\text { KarW = Number of female } \\
\text { employees to the total number of } \\
\text { employees }\end{array}$ \\
\hline $\begin{array}{l}\text { Female Board of Directors Gender } \\
\text { Composition }\end{array}$ & $\begin{array}{l}\text { DirW = Number of female board } \\
\text { members to the total number of } \\
\text { board of directors' members }\end{array}$ \\
\hline
\end{tabular}

Source: data processed

\section{RESULTS AND DISCUSSION}

\section{A. Results}

The average composition of female employees to the total number of employees is $49.40 \%$. Male employees outnumber the female employees. However, the number difference is not significant. Based on the research sample, there is a bank with female employees outnumbering the male employees up to $73 \%$ in percentage and another bank employing $40 \%$ female employees to the total number of employees.

The average composition of female in the board to the total number of board of directors' members is $37.25 \%$. The minimum number of female board member is $0 \%$ and the maximum number is $1 / 3$ of the board of directors is composed of female board members.

TABLE IV. DESCRIPTIVE

\begin{tabular}{|l|c|l|l|l|c|}
\hline \multicolumn{1}{|c|}{ Variable } & N & Minimum & Maximum & Mean & $\begin{array}{c}\text { Standard } \\
\text { Deviation }\end{array}$ \\
\cline { 1 - 5 } $\begin{array}{l}\text { KarW (Female } \\
\text { Employees) }\end{array}$ & 44 & 0.27 & 0.60 & 50.60 & 0,08131 \\
\hline $\begin{array}{l}\text { DirW (Female } \\
\text { Board } \\
\text { Members) }\end{array}$ & 44 & 0.00 & 1.50 & 37.25 & 0.34116 \\
\hline
\end{tabular}

Source: data processe

\section{B. Discussion}

1) Testing H1 (Employees Diversity on Return On Assets): The diversity of female employees does not give a significant contribution on Return on Assets of the banking institutions. This result shows that female employees do not influence the Return on Assets (ROA) significantly.

2) Testing H2 (Board of Directors Diversity on Return On Assets): The diversity of female board members gives a significant contribution on Return on Assets of the banking institutions. This result shows that female board members influence the Return on Assets (ROA) in negative and significant manners. This result supports 
the research Fatima and Sharif [26] and Khan [19]. However, this result is different from the results of the researches conducted by Moreno-Gómez et al. [4], Ramly et al. [7] and Elsharkawy et al. [16].

TABLE V. RESEARCH RESULT

\begin{tabular}{|l|l|l|}
\hline \multicolumn{1}{|c|}{ Variable } & Return On Asset & \\
\hline KarW & -0.113 & \\
\hline & $(0.529)$ & \\
\hline DirW & -0.106 & $* *$ \\
\hline & $(0,042)$ & \\
\hline R & 0.387 & $*$ \\
\hline Sig & 0.09 & 1) Number in () estimated standard error \\
2) & *) Significant on 10\% \\
& ***) Significant on 5\% \\
& ***) Significant on 1\% \\
& Source: data processed
\end{tabular}

\section{CONCLUSION}

By studying Book 4 and Book 3 banks from 2015 to 2018, the total number of bank analyzed in this research is 11 banks. The research result concludes that the diversity of female board members has a negative influence on banking performance, specifically on Return on Assets (ROA). The number of female employees does not influence on Return on Assets (ROA).

This research only analyzes Return on Assets to measure the performance. For future researches, more performance parameters such as profitability and efficiency should be analyzed to determine the results. Furthermore, this research only studies Book 3 and Book 4 banks, so the research result cannot be generalized

\section{REFERENCES}

[1] Republik Indonesia, Law of the Republic of Indonesia Number 7 of 2017 on Election. 2017.

[2] Statistics Indonesia, National Census on Women Empowerment and Women in Professional Workforce Indexes. 2018. 2018;

[3] R. Hassan and M. Marimuthu, "Corporate Governance, Board Diversity, and Firm Value: Examining Large Companies Using Panel Data Approach,” Econ Bull, vol. 36, no. 3, pp. 1737-50, 2016.

[4] J. Moreno-Gómez, E. Lafuente and Y. Vaillant, "Gender diversity in the board, women's leadership and business performance," Gend Manag., vol. 33 , no. 2, pp. 104-22, 2018

[5] M. Ionascu, I. Ionascu, M. Sacarin and M. Minu, "Women on boards and financial performance: Evidence from a European emerging market," Sustain, vol. 10, no. 5, 2018.

[6] R. Handa, "Does corporate governance affect financial performance: A study of select Indian banks," Asian Econ Financ Rev. vol. 8, no. 4, pp. 478-86, 2018.

[7] Z. Ramly, S.G. Chan, M.Z. Mustapha and N.S. Sapiei, "Women on boards and bank efficiency in ASEAN-5: the moderating role of the independent directors," Rev Manag Sci. vol. 11, no. 1, pp. 225-50, 2017.

[8] C. Volonté and P. Gantenbein, "Directors' human capital, firm strategy, and firm performance," J Manag Gov., vol. 20, no. 1, pp. 115-45, 2016.
[9] T. Nguyen, A. Nguyen, S. Locke and K. Reddy, "Does the human capital of board directors add value to firms? Evidence from an Asian market," Cogent Econ. Financ. vol. 5, no. 1, pp. 1-17, 2017.

[10] S.J. Mohammad, M. Abdullatif and F. Zakzouk, "The effect of gender diversity on the financial performance of Jordanian banks," Acad Account Financ Stud J. vol. 22, no. 2, pp. 1-11, 2018.

[11] M. Saleh, "Effect of Board of Directors' Attributes on the Financial Performance of Listed Deposit Money Banks in Nigeria," Dev Ctry Stud vol. 2, no. 10, pp. 1-15, 2018.

[12] R. Hassan, "Diversity, Corporate Governance and Implication on Firm Financial Performance," Glob Bus Manag Res An Int J. vol. 7, no. (2), 2015

[13] K. Širec and D. Mocnik, "A gender perspective of Slovenian highgrowth firm's profitability," Int J Entrep Small Bus. vol. 27, no. 2-3, pp. 247-61, 2016

[14] H.M. Jadah, L.A. Murugiah and A.B.A. Adzis, "The Effect of Board Characteristics on Iraqi Banks Performance. Int J Acad Res Accounting, Financ Manag Sci, vol. 6, no. 4, pp. 205-14, 2016.

[15] A. Shukla, N. Sivasankaran and S.A. Dasgupta, "Do board characteristics impact the market performance of Indian banks," Asian Econ Financ Rev., vol. 8, no. 11, pp. 1365-84, 2018.

[16] M. Elsharkawy, A.S. Paterson and M. Sherif, "Now you see me: Diversity, CEO education, and bank performance in the UK," Invest Manag Financ Innov., vol. 15, no. 1, pp. 277-91, 2018.

[17] H. Endraswati, "Gender Diversity in Board of Directors and Firm Performance: A Study in Indonesia Sharia Banks," Rev Integr Bus Econ Res., vol. 7, no. 1, pp. 299-311, 2018.

[18] M. Khan, "Effects of Education and Training on "Human Capital - And Effects of Human Capital," Int J Inf ethics, vol. 6, no. 3, pp. 90-105, 2014."

[19] M.H. Khan, A. Fraz, A. Hassan and P. Abedifar, "Board Gender Diversity, Risk-taking and Performance: Evidence from Dual Banking Systems," Work Pap Responsible Bank Financ WP No 19-003 [Internet]. 2018; Available from: https://ssrn.com/abstract=3302475 or http://dx.doi.org/10.2139/ssrn.3302475

[20] F. Arnaboldi, B. Casu, E. Kalotychou and A. Sarkisyan, The performance effects of board heterogeneity: what works for EU banks? Eur J Financ 2018:0(0):1-28. Available from: https://doi.org/1351847X.2018.1479719

[21] A.L.Owen and J. Temesvary, "The performance effects of gender diversity on bank boards," J Bank Financ, vol. 90, pp. 50-63, 2018.

[22] Dries J van den, The Effect of Gender Diversity and Quotas on the Performance of Banks: A Comparison Within Europe Master Thesis. 2018

[23] N. Zahoor, "Relationship between Gender Diversity in Top Management Teams and Profitability of Pakistani Firms," Journal of Resources Development and Management, vol. 16(1997), pp. 89-93, 2016.

[24] S.O. Abu, A.J. Okpeh and U.J. Okpe, "Board Characteristics and Financial Performance of Deposit Money Banks in Nigeria," Int J Bus Soc Sci., vol. 7, no. 9, pp. 159-73, 2016

[25] S. Chandani, M. Mabood and W. Mahmood, "The effect of women director on banks performance: Evidence from Pakistan,” Indep J Manag Prod. Vol. 9, no. 3, pp. 958, 2018.

[26] S. Fatima and S. Sharif, "Diversity and the Performance of Selected Financial Institutions of Asia," Sukkur IBA J Econ Financ, vol. 2, no. 1, pp. 31-50, 2018.

[27] Bank Indonesia Regulation of Bank Indonesia Number 14/26/PBI/2012 on Bank's Business Activities and Office Network based On Core Capital dated 27th December 2012 [Internet]. 2012. Available from: http://sibresearch.org/uploads/3/4/0/9/34097180/riber_7-s1_sp_s17138_299-311.pdf 